\title{
Letters
}

Website: bmj.com

Email: letters@bmj.com

\section{Open letter to the chief medical officer}

\section{Learning from Bristol: the need for a} lead from the chief medical officer

Dear Professor Donaldson,

The long awaited report of the inquiry into children's heart surgery at the Bristol Royal Infirmary has now been published. The report echoes many of the themes that you have developed and reiterated since you became chief medical officer. It notes, for example, that "error, once acknowledged, allows lessons to be learned" and that "learning from error, rather than seeking someone to blame, must be the priority."1

You have also recently explained in the $B M J$ how clinical governance will facilitate the delivery of quality care, which should be characterised by "a no blame, questioning, learning culture, excellent leadership, and an ethos where staff are valued and supported as they form partnerships with patients." Similarly, in the letter you sent to every doctor last month, you noted that there had not been a real appreciation of the frequency with which, when things go wrong, "the true cause lies in weaknesses within the system rather than culpable actions of an individual." Your letter also drew attention to a statement recently issued

\section{Advice to authors}

We prefer to receive all responses electronically, sent directly to our website. Processing your letter will be delayed unless it arrives in an electronic form.

We are now posting all direct submissions to our website within 24 hours of receipt and our intention is to post all other electronic submissions there as well. All responses will be eligible for publication in the paper journal.

Responses should be under 400 words and relate to articles published in the preceding month. They should include $\leqslant 5$ references, in the Vancouver style, including one to the BMJ article to which they relate. We welcome illustrations.

Please supply each author's current appointment and full address, and a phone or fax number or email address for the corresponding author. We ask authors to declare any competing interest. Please send a stamped addressed envelope if you would like to know whether your letter has been accepted or rejected.

Letters will be edited and may be shortened.

bmj.com

letters@bmj.com on behalf of the government, the medical profession, and the NHS which emphasised "the need to acknowledge "honest failure" and that "the first response should not be blame and retribution."

Few would wish to criticise your frequent promulgation of these principles. ${ }^{2-6}$ What puzzles us-and many other doctors-is why you and your colleagues in the civil service and government have not ensured that you use opportunities to set an example of the behaviour you expect of others. This open letter reflects our frustrating failure to be allowed to discuss these matters with you informally.

\section{Admitting systems failure}

Two days after the report of the Bristol inquiry appeared, a medical civil servant named in the report insisted on Radio 4 that the inquiry team was wrong to say that he "should have behaved differently." This is simply the most recent example of an unwillingness among civil servants to admit errors and to acknowledge the systems failures that these often reflect.

Over a year ago now, we sent you an advance copy of our assessment of the quality of an inquiry prompted by allegations about research on children in Stoke on Trent. ${ }^{7}$ Our draft report suggested that an inquiry team composed of two senior medical civil servants and one lay member had disregarded due process and produced a report that was full of factual errors and repeatedly blamed named individuals. Our purpose in making the findings of our investigation available to you well in advance of their publication in the $B M J^{8}$ was to ensure that we were able to correct any errors of fact in our report and also to give the department an opportunity to respond to our findings, indicating what systems might be put in place to avoid a recurrence.

A year later, none of our specific allegations has yet been refuted, either by the inquiry team or by the department. Worse still, in response to questions raised in the House of Lords about the quality of the inquiry, the minister responsible said he had "no reason to believe that the review was not conducted properly" and did not believe that it was "out of order or kilter with others which have taken place, or are taking place, within the NHS." ${ }^{9}$

The systems failure for which the department was responsible in this instance has never been openly admitted, but its nature was made very clear in the report of the inquiry into cardiac surgery at the Royal Brompton and Harefield Hospitals published earlier this year. The chapter describing their guiding principles and procedures begins: "We found there was neither precedent nor guidelines to draw on to help us run the Inquiry. This is surprising given the number of non-statutory reviews commissioned within the NHS." ${ }^{.10}$

\section{Scapegoating}

In 1994, based on your experience as a regional medical officer, you wrote in the $B M J$ that you had not resorted to suspension of NHS staff unless there was an immediate danger to patients. Your judgment then was that suspension "introduces an immediate stigma, increases the degree of confrontation, and makes informed and agreed solutions much more difficult." ${ }^{11}$ Commenting on another consequence of prolonged suspension in 1995, the current secretary of state, then a backbencher in opposition, is reported to have suggested that the prolonged suspension of a paediatrician in London had been an "expensive shambles for the NHS." 12 The Society of Clinical Psychologists says that the NHS suspended as many doctors in 1997-9 as in the previous 10 years, but incompetence was found on investigation in only 1 in 10 of those so charged. ${ }^{12}$ Clearly, allowing these doctors to continue working would not have posed "an immediate danger to patients"your only criterion for justifying immediate suspension. The government resisted attempts to get a bill curtailing prolonged suspension passed 16 months ago ${ }^{13}$ but has yet to announce a plan for curbing this practice.

The worst accusation levelled at the doctors and nurses in Stoke was that some research consent forms had been forged-an allegation that received very wide publicity, including an editorial in the $B M J .^{14}$ The General Medical Council has now ruled that these allegations were entirely false. ${ }^{15} \ldots$ If the Department of Health and managers at the NHS Trust really "valued and supported" the nurses and doctors in Stoke, they would have ensured wide publicity for this finding by now. One of the doctors in Stoke who was suspended 20 months ago has been exonerated and finally went back to work last month ${ }^{16}$; another still remains suspended.... As you have made clear, ${ }^{11}$ it is simply not possible to suspend NHS staff for months on end without prejudicing their reputations and destroying family life. ${ }^{17}$ While the 
Department of Health is aware that this can happen, ${ }^{18}$ it clearly does not share others' perception about the frequency with which suspension is seen retrospectively to have been inappropriate. A screening strategy that leads to more false positives than true positives risks doing more harm than good.

\section{A request}

The report of the Bristol inquiry concludes that "priority needs to be given to improving the leadership and management of the NHS at every level."' You and your civil servant and ministerial colleagues are responsible for leadership and management at the highest level of the service. It may be unrealistic to expect ministers to acknowledge any responsibility for system failures. But are we also wrong to hope that the country's most senior doctor could ensure that medical civil servants lead by example in this respect? It was wrong of the team responsible for the inquiry in Stoke on Trent to try to deflect continuing concern over the conduct of their inquiry simply by saying in their commentary that many of their recommendations were sound, ${ }^{8}$ when many of the findings of fact were in error and they had ignored the need for due process. ${ }^{8}$ We now know that new management systems are currently being developed. ${ }^{5}$ Nevertheless, an open admission of past systems failure by civil servants would help everyone to see why new arrangements are necessary and make it easier for others in the NHS to make similar admissions.

Yours sincerely,

Iain Chalmers director

UK Cochrane Centre, Oxford OX2 7LG

Edmund Hey retired paediatrician

Newcastle upon Tyne

1 Learning from Bristol. The report of the inquiry into children's heart surgery at the Bristol Royal Infirmary, 1984-1995. London: Stationery Office, 2001 (www.bristol-inquiry.org.uk/final_report/index.htm)

2 Halligan A, Donaldson L. Implementing clinical governance: turning vision into reality. BMJ 2001:322:1413-7.

National Health Service. A commitment to quality, a quest for excellence. Available at: www.doh.gov.uk/cmo/ quest for exce

4 Department of Health. An organisation with a memory. report of an expert group on learning from adverse events in the NHS chaired by the chief medical officer. London: Stationery Office, 2000

5 Department of Health. Building a safer NHS for patients: mplementing an organisation with a memory. Available at: www.doh.gov.uk/buildsafenhs

Mayor S. NHS introduces new patient safety agency. $B M$ 2001;322:1013.

7 NHS Executive West Midlands Regional Office. Report of a review of the research framework in North Staffordshire Hospital NHS Trust (Griffiths report). Leeds: NHS Executive, 2000. (www.doh.gov.uk/wmro/northstaffs.htm, updated 8 May 2000 )

8 Hey E, Chalmers I. [With commentary by R Griffiths, T E Stacey, J Struthers.] Investigating allegations of research Stacey, J Struthers.] Investigating allegations of research
misconduct: the vital need for due process. BMJ misconduct: the vital need

9 North Staffordshire NHS Trust. Hansard 10 October 2000 , cols 150-1

10 Evans $\mathrm{R}$ (chair). The report of the independent inquiries into paediatric cardiac services at the Royal Brompton Hospital and Harefield Hospital. London: Royal Brompton Hospital, 2001.

11 Donaldson LJ. Doctors with problems in an NHS workforce. BMJ 1994;308:1277-82.

12 Jones J. Hospital doctors face rising threat of suspension. BMJ 2000;321:72.

13 Suspension of Hospital Medical Practitioners Bill. Hansard 12 April 2000, cols 273-9.

14 Smith R. Babies and consent: yet another NHS scandal. BMJ 2000;320:1285-6.

15 Dyer C. Hospital chief was right to release patien consent forms to media. BMJ 2001;322:1266. (26 May.)
16 Ferriman A. Paediatrician to be reinstated. $B M J$ 2001;322:1085. (5 May.)

17 Anonymous. Recommendations for suspended doctor must be enacted. BMJ 2001;323:47. (7 July.)

18 Department of Health. Supporting patients, protecting patients-a consultation paper on preventing, recognising and dealing with poor clinical performance of doctors in the NHS in England. Available at: www.doh.gov.uk/cmoconsult.htm (para 2.51)

\section{Will primary care trusts lead to US-style health care?}

\section{The NHS is probably safe in the government's hands}

EDITOR-Pollock has presented a one sided view and explanation of some of the policy actions she suggests may drive the NHS towards a US-style health care system. ${ }^{1}$ Her view is that, as a result of a combination of historic and current policy changes, NHS trusts will be burdened with such large debts that they will be forced to embark on several actions that will raise "the spectre of US-style health maintenance organisations."

But her initial premise (of rising cost pressures) is a bit wobbly.

Firstly, although capital charges do indeed represent a cost to trusts in the NHS, these are not new. Introduced as part of the internal market, they were matched on the purchasing side so that the net sum across the NHS was zero.

Over time, the direct link between an individual trust's charge and the compensating money given to its purchasers has been broken. Providers have had to think more carefully about their use of capital. Overall, this is a good thing as capital, like labour, is not a free good in the NHS: its cost can be measured in the forgone benefits of using resources in some alternative way.

Secondly, the repayments that trusts have to make on any private finance initiative or public-private partnership deal are, again, as Pollock points out, also a cost but one that is also recovered from purchasers. Just as publicly funded capital schemes are paid for from the Exchequer, so private finance initiative schemes are ultimately paid for by the Exchequer (out of taxation), but the route is different (via purchasers' allocations rather than a direct (repayable) grant from the Exchequer). ${ }^{2}$

Thirdly, although the repayments overall will escalate over the coming years, this is

Mean required and actual capital charges per NHS trust (£000). Values are for all NHS acute care trusts in England, 1992-8 inclusive

\begin{tabular}{lccccccc} 
Year & No of trusts & $\begin{array}{c}\text { Average } \\
\text { total income }\end{array}$ & $\begin{array}{c}\text { Average } \\
\text { operating } \\
\text { surplus }\end{array}$ & $\begin{array}{c}\text { Surplus as } \\
\text { \% income }\end{array}$ & $\begin{array}{c}\text { Required } \\
\text { capital } \\
\text { charges* }\end{array}$ & $\begin{array}{c}\text { Actual } \\
\text { capital } \\
\text { charges } \dagger\end{array}$ & Shortfall \\
\hline 1992 & 42 & 61712 & 4578 & 7.4 & 6593 & 6484 & 109 \\
\hline 1993 & 92 & 60560 & 3400 & 5.6 & 6328 & 5550 & 778 \\
\hline 1994 & 169 & 62690 & 3828 & 6.1 & 6183 & 5530 & 653 \\
\hline 1995 & 235 & 65743 & 3468 & 5.3 & 6189 & 5418 & 771 \\
\hline 1996 & 241 & 69586 & 2904 & 4.2 & 6586 & 5650 & 936 \\
\hline 1997 & 239 & 74081 & 2950 & 4.0 & 7010 & 6293 & 717 \\
\hline 1998 & 238 & 77745 & 3315 & 4.3 & 7372 & 6979 & 393 \\
\hline All & & & & & 46261 & 41904 & 4357 \\
\hline
\end{tabular}

Source: Fitzhugh Directory of NHS Trusts. ${ }^{*} 6 \%$ on capital value plus depreciation. $†$ Surplus (to pay interest and dividends) plus depreciation. simply because the government is keen to see more deals struck under the initiative.

Having apparently established that trusts will be facing a mounting bill for capital, Pollock then states that unless more money is injected into the NHS to help meet these costs, patient and clinical services will be under threat, or other unpleasant actions will have to be taken that will destroy the NHS as we know it

But, of course, more money has been allocated to the NHS. And part of this pays for private finance initiative costs and will flow from purchasers to providers with private finance initiative and public-private partnership deals, and on to private consortiums (which paid for and built NHS facilities). If these schemes had been funded via the conventional public route then some of the settlement would have been used in this way instead. Either way, it could be interpreted (as Pollock has done) as threatening patient services (although I would have thought that hospitals and other facilities are generally seen by most people as an integral part of patient services).

There are legitimate arguments against the private finance initiative and publicprivate partnership, but in this paper Pollock fails to articulate them.

John Appleby director, health systems programme King's Fund, London W1M OAN j.appleby@kehf.org.uk

1 Pollock AM. Will primary care trusts lead to US-style

2 Sussex J. The economics of the private finance initiative in the NHS. London: Office of Health Economics, 2001

\section{Authors' reply}

Editor-Contrary to Appleby's assertion, the introduction of capital charges on NHS trusts in the 1990s has had strongly negative effects on trust assets and trust finances.

Aggregated financial accounts of NHS acute hospital trusts in England for 1992-8 inclusive show that trusts as a whole failed to make the $6 \%$ target rate of return in all years except 1992 and 1995 (table). Even then, many trusts were unable to break even after paying interest. The cost of capital charges to the NHS as a whole might have been zero; but their average cost to each NHS when the government collected the full $6 \%$ ) was $£ 393000$. In fact, the situation was so health care? BMJ 2001;322:964-7. (21 April.) acute hospital trust in 1998 (the first year 
parlous that the Department of Health decided not to collect the full 6\% until 1998 .

Capital charges deterred trusts from undertaking what the Department of Health regarded as a reasonable amount of expenditure for capital goods. In the first three years of their operation, NHS acute hospital trusts in England underspent on their capital budget by an average of $£ 200000$ a year. $^{1}$ Between 1993 and 1997 NHS backlog maintenance costs rose from $£ 2.4 \mathrm{bn}$ to £3.1bn. ${ }^{2}$ Capital charges have had a strongly negative impact on the capital base of the NHS (and especially on planned capital expenditure). The loss of capacity has been regretted in the report of the national beds inquiry and in the NHS plan. ${ }^{34}$

The comprehensive spending review allows for average annual real term increases of $6.1 \%$ in NHS funding in the United Kingdom over the four years to 2003-4. Many trusts report annual cost pressures of $6 \%$ just to maintain current service levels. Moreover, the annual cost of capital to hospitals built under the private finance initiative has risen from an average of $9 \%$ to up to $20 \%$ of their revenue budgets. Average bed losses were $30 \%$ in the first 11 such hospital schemes, and reductions in clinical budgets were up to $20 \%{ }^{5} \mathrm{~A}$ full list of publications relating to the private finance initiative is at www.ucl.ac.uk/spp/about/ health.htm

A M Pollock professor

Health Policy and Health Services Research Unit,

School of Public Policy, University College London, London WC1H 9OU

hp-hsru@ucl.ac.uk

J Shaoul senior lecturer

School of Accounting and Finance, University of Manchester, Manchester M13 9PL

N Vickers research fellow

Health Policy and Health Services Research Unit, University College London

A longer version of this letter is published on bmj.com

1 Shaoul J. NHS trusts: a capital way of operating. Manchester: Manchester University, 1996. (Working paper.)

Department of Health. The government's expenditur plans-1998-1999. London: Stationery Office, 1998. (Cm 3912.)

3 Department of Health. National beds enquiry. London DoH, 2000.

4 Department of Health. The NHS plan. London: DoH, 2000. 5 Pollock AM, Dunnigan MG, Gaffney D, Price D, Shaoul J. Planning the "new" NHS: downsizing for the 21st century. BMJ 1999;319:179-84.

\section{Antidepressants and counselling for major depression in primary care}

\section{Authors' conclusions were not justified by findings}

EDITOR-In their randomised trial of antidepressant drugs and generic counselling for treating depression, Chilvers et al concluded that generic counselling is as effective as antidepressants and that general practitioners should allow patients to have their preferred treatment. ${ }^{1}$ Their findings do not, however, support these conclusions.
The authors based their sample size calculation on a difference in mean Beck scores of 5 points as the outcome and found that 44 patients in each arm were required for a power of $80 \%$. This sample size was not achieved in the randomised arms. They did not calculate the sample sizes required for global outcome or remission, but they are likely to be much larger as these outcome variables are categorical. Therefore, the only finding which achieved a power of $80 \%$ was related to Beck scores in the combined group of randomised patients and patients expressing preference.

Both general practitioner's rating and the score for research diagnostic criteria in table 1 show that patients choosing counselling were objectively significantly less depressed than the other groups, although their Beck inventory scores were similar. In other words, compared with the other groups, patients choosing counselling were comparatively more depressed subjectively than objectively. These patients were less depressed objectively and might respond more readily than other groups to interventions. Therefore, Chilvers et al should not have combined randomised patients with patients who expressed a preference. Furthermore, they cannot conclude that generic counselling is as effective as antidepressants simply from the apparent lack of differences in Beck scores in the combined patients who expressed a preference.

Chilvers et al further concluded that general practitioners should allow patients to have their preferred treatment. While this recommendation might be appropriate, it does not follow from their findings. To draw this conclusion, the authors would need to compare the outcomes of patients who chose a specific treatment and were offered it with those who requested the same treatment but were offered another treatment instead.

Wai-Ching Leung honorary lecturer in public health medicine

University of East Anglia, Norwich NR4 7T]

w-c.leung@uea.ac.uk

Competing interests: None declared.

1 Chilvers C, Dewey M, Fielding K, Gretton V, Miller P, Palmer B, et al for the Counselling versus Antidepressant in Primary Care Study Group. Antidepressant drugs and generic counselling for treatment of major depression in primary care: randomised trial with patient preference arms. BMJ 2001;322:722-5. (31 March.)

\section{Measuring preference in primary care} studies could be improved

EDITOR-The study by Chilvers et al is one of a few supporting a relation between receipt of preferred treatment and improved outcome in treating depression. ${ }^{1}$ The patients who chose counselling did better than those randomised to counselling, although the $95 \%$ confidence interval reached zero but but did not cross it.

Many patients express a preference for psychological compared with drug treatments. ${ }^{2}$ However, being allowed to choose treatment does not improve short term outcome in depressed patients in primary care given either antidepressants or counselling ${ }^{3}$ or non-directive counselling, cognitivebehaviour therapy, or usual general practitioner care. ${ }^{4}$

This difficulty in showing the effects of preference may be methodological. As in the current study, preference has been defined as refusal to be randomised within a trial. However, many patients might be prepared to allow themselves to be randomly allocated treatment but would still prefer not to receive the treatment to which they are allocated, diluting the beneficial effects inherent in the preference arm.

An alternative method would be to randomise the entire population and then allow patients to accept or decline the allocated treatment. In this procedure the consent process would be split in two, with patients initially consenting to take part in the study on the understanding that a treatment will be offered but does not have to be accepted, followed by a second stage in which they accept or decline the treatment. Those who decline remain in the study but are treated as the general practitioner believes is clinically appropriate. This gives three groups that can be compared-the whole cohort, those who accept randomisation, and those who decline it-and it allows the effects of preference to be described in more detail.

Andrew Martyn Thornett clinical research fellow Department of Psychiatry, University of Southampton, Southampton SO14 0YG eanador@soton.ac.uk

Competing interests: None declared.

1 Chilvers C, Dewey M, Fielding K, Gretton V, Miller P, Palmer B, et al for the Counselling versus Antidepressants in Primary Care Study Group. Antidepressant drugs and ceneric counselling for treatment of major depression in generic counselling for treatment of major depression in primary care: randomised trial with

arns. BM) 2001;322.722-5.(31 March.) Priest RG, Vize C, Roberts A, Tylee A. Lay people's treatment of depression. BMJ 1996;313:

3 Bedi N, Chilvers C, Churchill R, Dewey M, Duggan C, Fielding K, et al. Assessing effectiveness of treatment of depression in primary care. Partially randomised preference trial. BrJ Psychiatry 2000;177:312-8.

4 Ward E, King M, Lloyd M, Bower P, Sibbald B, Farrelly S, et al. Randomised controlled trial of non-directive counselling, cognitive-behaviour therapy, and usual general practitioner care for patients with depression. I. Clinical effectiveness. BMJ 2000;321:1383-8.

\section{Counselling is not demonstrably as} effective as drug treatment for depression

EDitor-The study by Chilvers et al investigating the effect of antidepressants and generic counselling in depression has flaws in its design and interpretation. ${ }^{1}$ Its recommendations are not supported by its findings.

The main outcome measure discussed is based on the Beck depression score at 12 months. However, many people who start off being depressed will not be so 12 months later even without treatment, and the main effect of antidepressants is to accelerate what will often be a spontaneous recovery. Hence outcome at 12 months is insensitive as a guide to the effectiveness of any treatment for depression. Also, a substantial proportion of patients will improve fairly quickly with placebo, but Chilvers et al did not provide a placebo for either the drug or 
the psychological treatment. There were not even "waiting list controls." Hence it is impossible to know whether, in the context of this study, either treatment has any effect whatsoever, either in accelerating recovery or in producing a good outcome at 12 months.

Chilvers et al state that both counselling and antidepressant drugs are effective. For the above reasons, their study provides no evidence at all to support this assertion. One of the bullet points in the box entitled "What this paper adds" states: "12 months after starting treatment, generic counselling is as effective as antidepressants." Again, there is no evidence for this. Presumably the authors are making the classic mistake of equating the failure to show a difference with showing no difference. In fact, of the randomised patients who were followed up, 78\% who received drugs were no longer depressed compared with $47 \%$ who received counselling. Another bullet point states: "Patients treated with antidepressants may recover more quickly" [my italics], but the text simply states that they did recover more quickly. However, no data relating to time to remission appear anywhere in the results section. Results showing the superiority of antidepressants seem not to have been presented.

Overall, much evidence suggests that antidepressants and some psychological treatments are effective in alleviating depression, but this is not the case for generic counselling. The study by Chilvers et al provides no useful information, and the authors have no business recommending that "general practitioners should allow patients to have their choice of treatment." Following this recommendation would be expected to lead to an avoidable increase in morbidity and mortality from depressive illness while squandering public resources on providing counselling, which is of no proved benefit for this condition.

David Curtis consultant psychiatrist East London and City Mental Health NHS Trust, Royal London Hospital, London E1 1BB

Competing interests: None declared.

1 Chilvers C, Dewey M, Fielding K, Gretton V, Miller P, Palmer B, et al for the Counselling versus Antidepressants in Primary Care Study Group. Antidepressant drugs and generic counselling for treatment of major depression in primary care: randomised trial with patient preference arms. BMJ 2001;322:722-5. (31 March.)

\section{Authors' reply}

EDITOR-Leung rightly points out that our calculation for sample size was based on Beck scores, the primary outcome measure in our trial of antidepressant drugs and generic counselling for the treatment of depression. The main results based on the Beck scores shown in table 2 of our paper are adjusted for baseline scores for research diagnostic criteria, as well as for patient preference or randomised group. Leung seems to suggest that the doctor's report of depression is to be preferred to the patient's. We remain to be convinced.

Both Leung and Thornett draw attention to the difficulty of assessing the effect of patient preference on outcome. Although Leung's suggestion may have some theoretical justification, there would be practical problems in carrying it out. Patients would have to agree to express a preference and then accept the treatment that they did not prefer. We would argue that those consenting to enter such a trial would not have strong preferences and we probably would be no further forward. In Thornett's design the group accepting the allocated treatment would consist of those preferring the allocated treatment and those who were indifferent, thus diluting the effect of preference.

Curtis considers that our trial should have included a placebo arm. He also believes that there is plenty of evidence that antidepressants and some psychological treatments are effective. We did not consider it ethical to include a placebo arm.

With reference to our statement that patients taking antidepressants recover more quickly, the median times are given in the electronic version but not in the paper one. Median time to remission was three months in all groups except the group randomised to antidepressants, where the median time to remission was two months (comparing randomised groups log rank statistic 2.74, $\mathrm{P}=0.1$; pooled $\log$ rank statistic for randomised and patient preference trials $0.82, \mathrm{P}=0.36)$. Thirty three $(15 \%)$ of the 221 patients had a relapse. There were no differences between the groups.

Having shown that generic counselling is as effective as antidepressant treatment, we recommend that patients should be allowed to choose between two effective treatments, thus allocating a scarce resource (counselling) to those who find it most acceptable Further analyses (in preparation) suggest that the costs of the two treatments are similar.

\section{Clair Chilvers professor}

Michael Dewey senior lecturer

michael.dewey@nottingham.ac.uk

Trent Institute for Health Services Research,

University of Nottingham Medical School, Queen's Medical Centre, Nottingham NG7 2UH

Also signed by the 11 other authors: Katherine Fielding (lecturer), Virginia Gretton (research assistant), Paul Miller (lecturer in health economics), Ben Palmer (research associate), Trent Institute for Health Services Research; David Weller (professor), University of Edinburgh; Richard Churchill (lecturer), Idris Williams (professor), University of Nottingham Medical School; Navjot Bedi (specialist registrar in psychiatry), Nottingham Healthcare NHS Trust; Conor Duggan (professor), University of Leicester; Alan Lee (consultant psychiatrist and special senior lecturer), University Hospital, Queen's Medical Centre; and Glynn Harrison (professor), University of Bristol.

On behalf of the Counselling versus Antidepressants in Primary Care Study Group.

\section{Revised Declaration of Helsinki}

\section{Ethics is not just for ethicists}

EDITOR-Singer and Benatar's editorial on revisions of the Declaration of Helsinki proposes "capacity development," defined as an increased number of professionals trained in ethics. ${ }^{1}$ Although this is indeed a step that needs to be taken, I cannot agree that it alone will advance the cause of ethical research, especially with the plans that the authors propose.

The assumption that having more trained people will change the system satisfies a necessary but not sufficient criterion. The fact that there are more doctors in the developing world today than there were 20 years ago does not mean either that the practice of medicine is better or that health needs are addressed. It depends on what these people trained in ethics do, where they do it, how they sustain their efforts, and how they integrate their contributions within the overall health development of nations.

The numbers and budgets presented in the proposal are simply arbitrary-they are not defended and so are difficult to evaluate. If $\$ 100 \mathrm{~m}$ is available, what are the alternative pathways for investment for the developing world? If one considers all the health and staffing needs then the need for ethics training may not be the most important: community health workers, trained birth attendants, and others may be higher on the list. Another major issue is where the money goes. Implicit in the editorial is that the money will have to go to training centres in the West. This means that $90 \%$ of the money is not going to the developing world-a feature of "aid" well known to those in the South.

The editorial severely underplays the role of other stakeholders. The importance of roles for professionals from a wide variety of disciplines, of decision makers, of community leaders, and of business leaders in shaping the practice of ethics in the South needs to be recognised. A "global alliance for health ethics" and the proposed influence on the World Bank and World Trade Organisation are only distant visions. Is this the most effective or most efficient way to achieve that vision? Activists, lobbyists, and social scientists will beg to differ.

As long as ethics is viewed as something that is only for ethicists, or for those who have only been trained, it will never have the profound influence we all hope that it will have in both the developing and developed world.

Adnan A Hyder assistant research professor Johns Hopkins University, School of Public Health, Baltimore, MD 21205, USA

ahyder@jhsph.edu

$\mathrm{AAH}$ is the recipient of one of the ethics training grants from the Fogarty International Center of the National Institutes of Health.

1 Singer PA, Benatar SR. Beyond Helsinki: a vision for global health ethics. BMJ 2001;322:747-8. (31 March.)

WMA will continue to revise policy as medicine and research changes

EDITOR-The BMJ has devoted considerable coverage to the revision of the World Medical Association's Declaration of Helsinki. ${ }^{2}$ The declaration and its revision have greatly increased the global research community's sensitivity to research ethics. 
Although there can be little disagreement with the general sentiments expressed in Singer and Benatar's editorial on the declaration, ${ }^{3}$ some remarks are necessary to balance the arguments put forward. The authors state that "revisions ... are unlikely to make research more ethical throughout the world." The revision process of the Declaration of Helsinki contradicts this statement in the sense that increased awareness of ethical principles should improve ethical behaviour in research; the revision has already had an impact on clinical research.

The revision process, which entailed wide consultation and numerous intense debates among the different stakeholders in research, contributed much to a greater sensitivity to ethical behaviour in research. One example of its effectiveness was the increase in interest in the World Medical Association's policy. Visits to the association's website (www.wma.net), and specifically the section on the association's policy, had grown from seven a month in May 1998 to 220000 visits a month by October 2000 .

The revision has already had an impact on research, hopefully in a positive manner. The World Medical Organisation organised a conference on the ethical implications and implementation of the revised declaration in March this year in Pretoria, South Africa, which was attended by government regulators and some of the world's leading pharmaceutical companies, researchers, and ethicists. During this conference a representative of a large pharmaceutical company in Britain mentioned that since October 2000 up to eight new trials had been either disallowed or postponed because of the new guidelines in the declaration. ${ }^{4}$ All of these rulings were based on the article in the declaration concerning the ethical use of placebo controlled trials (article 29).

While congratulating the authors on their call for increased capacity, we would emphasise the importance of the revision of internationally accepted ethical codes, of which the Declaration of Helsinki is probably the most well known. The World Medical Association is committed to continue this process of revising policy as the medical and research environment changes, always using as its first consideration the best interests of patients.

Delon Human secretary general

World Medical Association, Boite Postale 63, Ferney-Voltaire, 01212, Cedex, France delon@wma.net

Francis Crawley executive director European Forum for Good Clinical Practice, B-3010, Kessel-Lo, Belgium

Carel IJesselmuiden head

School for Health Systems and Public Health,

University of Pretoria, PO Box 667, Pretoria, 0001

South Africa

1 Rothman KJ, Michels KB, Baum M. For and against: Declaration of Helsinki should be strengthened. $B M$ 2000;321:442-5.

2 Christie B. Doctors revise Declaration of Helsinki. BMJ 2000;321:913.

3 Singer PA, Benatar SR. Beyond Helsinki: a vision for global health ethics. BMJ 2001;322:747-8. (31 March.)

4 Bmj.com news roundup: Ferriman A. WMA agrees to refine changes to Declaration of Helsinki. BMJ 2001:322:1142.

\section{Authors' reply}

EDITOR-Hyder seems to misunderstand our proposal. Of course advancing the cause of ethics depends not simply on training people but on what they are trained to do. This would include research, advocacy, and strengthening the capacity of others such as members of research ethics boards. A key factor for success is that the funds should primarily be used for direct support of ethics centres in developing countries. We referred to this in our editorial as "the crucial step, yet to be taken."

There are indeed other capacity strengthening needs in global health, but to trade them off against each other is short sighted, and the other areas that Hyder mentions also have important ethics aspects that are addressed by our proposal. The figure of $\$ 100 \mathrm{~m}$ does not come with a detailed budget justification in an editorial. It is a rough calculation intended to give a sense of scale-and of how relatively little it would cost to achieve such an important effect.

Our vision would need to be pursued in a multidisciplinary manner with multiple stakeholders and careful attention to governance. Ethics will have minimal effect if its intended audience is only ethicists. We don't envision that the trainees would be professional philosophers but rather that they would be an interdisciplinary group. They would all be opinion leaders who could use their ethics training to influence others. Our vision is an outward looking one in which ethics is a vehicle for improving social and economic policies beyond the direct healthcare setting-in relation to, for example, research, genomics and biotechnology, and end of life care in developing countries.

We also wish to comment on Human et al's letter. We are not calling for an abandonment of international codes of ethics, or for these codes never to be updated. Our main point is that incremental change, such as revising a code, is necessary but not sufficient. To make a dramatic leap forward in global ethics (in this case, research ethics) more fundamental change and innovation are needed.

Our proposal for fundamental change is a commitment to broadening and strengthening capacity in ethics in developing countries. The balance until recently in international research ethics was $100 \%$ codes, $0 \%$ capacity strengthening. We would like to see this balance tilt more towards capacity strengthening. The Fogarty Bioethics Research and Education Program is an important first step, and we outlined further steps in our editorial. But editorialising is not enough: it is time for action.

Peter A Singer Sun Life financial chair University of Toronto Joint Centre for Bioethics, Toronto, ON, Canada M5G 1L4 peter.singer@utoronto.ca

Solomon R Benatar director

Bioethics Centre, University of Cape Town, Observatory 7925, Cape, South Africa

\section{High caesarean section rates among women over 30}

\section{Effect of age is continuous and international}

EDITOR-Bell et al's finding that rates of caesarean section increase with age ${ }^{1}$ are similar to findings from our analysis of all 103883 births in New Zealand hospitals between 1 July 1996 and 30 June 1998. Interestingly, our analysis shows that rates of caesarean section increase in a continuum from teenage years upwards: there was no age from which the increased likelihood of the operation first began to be noticed. Similar findings have been noted previously from, among other places, Britain, Jordan, ${ }^{4}$ and Italy.

Our analysis shows that women who are having a repeat caesarean section explain some of the increase, but a steady increase is still present in women who have not had a previous caesarean section. Rosenthal and Paterson-Brown suggest that this may be related to physiological changes with increasing maternal age.

The remarkably consistent finding from diverse countries about the effect of age led us to conclude that it is unlikely to be a result of clinical practice or societal pressures.

John C Marwick principal technical specialist John_marwick@moh.govt.nz

Robert Lynn senior adviser

Ministry of Health, PO Box 5013, Wellington 6040 New Zealand

1 Bell JS, Campbell DM, Graham WJ, Penney GC, Ryan M, Hall MH. Do obstetric complications explain high caesarean section rates among women over 30 ? A retrospective analysis. BMJ 2001;322:894-5. (14 April.)

2 Ministry of Health. Obstetric procedures 1988/89-1997/98. Wellington: Ministry of Health, 1999. (www.moh.govt.nz)

3 Rosenthal AN, Paterson-Brown S. Is there an incremental rise in the risk of obstetric intervention with increasing maternal age? Br J Obstet Gynaecol 1998;105:1064-9.

4 Abu-Heija A, Rasheed R, el-Qaran O. Effect of age and Abu-Heija A, Rasheed R, el-Qaraan O. Effect of age and parity on primary cae

5 Parazzini F, Pirotta N, La Vecchia C, Fedele L

Parazzini F, Pirotta N, La Vecchia C, Fedele L.
Determinants of caesarean section rates in Italy. Br J Obstet Gynaecol 1992;99:203-6.

\section{High rates may be due to perceived potential for complications}

Editor-Bell et al show that the higher caesarean section rate among older women is not entirely explained by their tendency towards more complicated pregnancies and births. ${ }^{1}$ They speculate that doctors' and maternal preferences might be contributory factors. An associated factor might be uncertainties related to the perceived potential for complications.

In a rapid response Quadros summarised the rising rate of caesarean section in just a few words: convenience and fear. ${ }^{2}$ As part of our research into women's choice and decision making in caesarean section we interviewed obstetricians and midwives, and women who had, or considered having, a caesarean section.

Many obstetricians told us that the number of women who requested a caesarean section purely for convenience was comparatively low. In fact, the postoperative recovery period after a caesarean section is 
weeks rather than the days it usually takes to recover from normal birth. We found that although women might be unaware of the morbidity for mother and baby usually associated with caesarean section, they do generally know about its debilitating effect.

The issue of fear is more complex. Some women strongly fear childbirth, ${ }^{45}$ sometimes because of how pregnancy and birth are managed. In large obstetric units, women may have many investigations, with additional monitoring for potential problems. Such hypervigilance can make younger women think that birth must be risky. In older women it is assumed, a priori, that they may have a complicated birth, just by virtue of their age. The additional psychological stress of being considered high risk and, as a result, possibly being subjected to even more monitoring might underlie an unacceptable fear of both vaginal birth and things going wrong. This could lead both to requests for caesarean sections from women and to increased willingness to perform them among obstetricians.

Every caesarean section performed on an older woman will enter statistics that are often used to show that such women have more problems giving birth vaginally; they also become part of the culture of childbirth that instils fear of birth in other pregnant women. Thus fear perpetuates fear. Older women do have extra problems, but concern about complications might be as much of a problem as the complications themselves.

Jane Weaver research associate

Helen Statham senior research associate

Martin Richards director

Centre for Family Research, Cambridge CB2 3RF

janejweaver@hotmail.com

1. Bell JS, Campbell DM, Graham WJ, Penney CC, Ryan M, Hall MH. Do obstetric complications explain high caesarean section rates among women over 30 ? A retrospective analysis. BMJ 2001:322:894-5. (14 April.)

2 Quadros LGA. Convenience and fear [electronic response to Bell JS et al. Do obstetric complications explain high caesarean section rates among women over 30? A retrospective analysis]. bmj.com 2001. www.bmj.com/cgi/ eletters/322/7291/894\#EL2 (accessed 17 Jul 2001.)

3 Weaver JJ. RCM Research Network. A study of choice and decision making in caesarean section. RCM Midwives J 2000;3:77

4 Weaver JJ. Talking about caesarean section. MIDIRS Midwifery Digest 2000;10:487-90.

5 Statham H, Weaver J, Richards M. Why choose caesarean section? Lancet 2000;357:635.

\section{Health benefits from genetics should be basic human right}

EDITOR-Bloom and Trach's editorial about genetics and developing countries seems to imply three things': that the human genome project has refuted biological justification for racial discrimination; that those living in the poorest countries should be grateful for this; and that, although genetic discrimination against these people is unacceptable, economic discrimination (which will deny them the possible health benefits of genetic knowledge) should be accepted as public policy. These suggestions are unacceptable on factual, historical, and moral grounds.

The crux of racism lies in the claim of members of certain dominant ethnic groups to an intellectual and cultural superiority that can be traced to their biological make up. Genetic evidence to refute or support this claim would require identification of the specific genetic determinants, if any, of the above traits. Since this has not been done yet it seems premature to make any assertions in the matter.

I suspect that the repeated assertions by the human genome project's scientists that the sequencing data do not justify racism are more of an attempt to dissociate genetics from its eugenic past (and potential) than a rigorous inference from the sequencing data. For some time before the second world war eugenics was fashionable in the United Kingdom, the United States, and Germany. It culminated in the Nazi racial hygiene experiments on Jews, which led to revulsion and the political stand against racism.

In support of this stand, geneticists pointed out that, in general, heritable traits show higher variability within populations (ethnic groups) than between them. Not surprisingly, the sequence data from the human genome project are consistent with this generalisation. However, two points are noteworthy here. Firstly, this generalisation is not applicable to every gene or group of genes. Indeed, several genetic diseases are known to occur more frequently in specific ethnic groups. Secondly, since eugenics and racial hygiene claimed most of their victims in rich countries poor people do not have to be extra grateful when these ideas are scientifically refuted.

Instead of the scientists and governments of poorer countries being advised to accept an economics based apartheid, they should be made aware of the high genetic potential of their people. This genetic potential should permit them to achieve the levels of development obtaining in the advanced countries. Health benefits based on genetic knowledge should be a basic human right

Suresh K Mahajan head

Molecular Biology and Agriculture Division, Bhabha Atomic Research Centre, Mumbai-400 085 , India

sk_mahajan@yahoo.com

1 Bloom BR, Trach DD. Genetics and developing countries. BMJ 2001;322:1006-7. (28 April)

\section{Beware of cytogenetic results after successful bone marrow transplantation}

EDITOR-Bone marrow transplantation is used in several haematological diseases, such as acute and chronic leukaemia, aplastic anaemia, and severe congenital immunodeficiencies. ${ }^{1}$ The survival rate has improved greatly over the past decade. ${ }^{2}$ Patients who have had successful bone marrow transplantation have peripheral blood cells originating from the donated bone marrow, and results of cytogenetic studies of these blood cells will relate to the donor. This is an important point to note if confusion is to be avoided, as was the case with two patients who presented to our centre.

Two male patients attended our unit with their spouses for infertility treatment.
The cause of infertility in both cases was intensive radiotherapy and chemotherapy before allograft bone marrow transplantation. One patient (case 1) was 28 years old and the other (case 2) 31 years old. Acute lymphoplastic leukaemia had been diagnosed in both in 1998. The treatment of choice in both cases is intracytoplasmic sperm injection. In our centre we perform karyotype and cystic fibrosis status screening on all patients undergoing this treatment.

Chromosome analysis in case 1 showed $46, \mathrm{XX}$, as the bone marrow donation was from a female patient. The patient in case 2 was shown to be heterozygous for cystic fibrosis gene DF508. We noted, however, that he had received his bone marrow transplant from his brother. The cystic fibrosis carrier state was subsequently shown to be related to the brother, as molecular testing of stored DNA extracted from a blood sample obtained before the bone marrow transplantation showed normal cytogenetics.

We were not aware of this possibility before encountering these cases, and nor were colleagues working in other infertility centres. It is, however, well known to haematologists who use cytogenetic examination for monitoring the period after transplantation in patients with chronic myeloid leukaemia or in those who received bone marrow cells from a patient of opposite sex. ${ }^{13}$

The number of patients in whom bone marrow transplantation has been successful has increased recently, and these patients are expected to live longer. They may require cytogenetic studies during their life, and healthcare professionals should be aware of the possible pitfalls. Stored DNA extracted from a blood sample obtained before transplantation may be used to avoid any confusion. Alternatively, karyotyping could be done on fibroblasts from a skin biopsy.

Nahed Hammadieh clinical research fellow in reproductive medicine nahed_hammadieh@hotmail.com

Khaldoun Sharif consultant obstetrician and gynaecologist

Masoud Afnan consultant obstetrician and gynaecologist

Spyros Papaioannou clinical research fellow in reproductive medicine

Bolaride Ola clinical research fellow in reproductive medicine

Assisted Conception Unit, Birmingham Women's Hospital, Birmingham B15 2TG

1 Zemanova Z, Michalova K, Musilova J, Lukasova M, Stary J Sequential cytogenetic study of patients after bone marrow transplantation. Cancer Genet Cytogenet 1994;72:68-72.

2 Snyder DS, Nademanee AP, O'Donnell MR, Parker PM, Stein AS, Margolin K, et al. Long-term follow-up of 23 patients with Philadelphia chromosome-positive acute lymphoblastic leukaemia treated with allogeneic bone marrow transplant in first complete remission. Leukaemia 1999;13:2053-8.

3 Sessarego M, Frassoni F, Defferrari F, Bacigalupo A, Miceli S, Mareni C, et al. Cytogenetic follow-up after bone marrow transplantation for Philadelphia-positive chronic myeloid leukaemia Cancer Genet Cytogenet 1989:42:253-61.

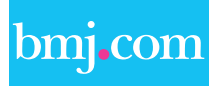

\section{Rapid responses}

Correspondence submitted electronically

is available on our website 